\title{
ANALISIS PROSES DAN ESENSIALITAS PADA TRADISI MANDI BAKUMBO DALAM PERNIKAHAN ADAT MELAYU DI KECAMATAN LIMA PULUH KOTA PEKANBARU PROVINSI RIAU
}

\author{
Wan Annisa Permatasari ${ }^{1^{*}}$, Agustina $^{2^{*}}$ \\ Program Studi Pendidikan Ilmu Pengetahuan Sosial Konsentrasi Pendidikan Seni dan Budaya \\ Program Pascasarjana \\ Universitas Negeri Padang \\ Jl. Prof. Dr. Hamta, Air Tawar Padang, Kel. Air Tawar Barat, Kec. Padang Utara, Kota Padang, Kode Pos 25171 \\ Sumatera Barat. Indonesia \\ Email: wanannisa30@gmail.com,tien_agustina08@yahoo.com
}

\begin{abstract}
Abstrak
Penelitian ini bertujuan untuk mendeskripsikan prosesi dan esensi acara Mandi Bakumbo dalam pernikahan adat Melayu di Pekanbaru Provinsi Riau. Pendekatan yang digunakan untuk mengurai hasil penelitian adalah pendekatan seni, budaya dan esensi. Metode penelitian yang digunakan adalah kualitatif deskritif. Pengumpulan data dilakukan dengan Observasi (dokumentasi) dan Wawancara (Interview). Teknik analisis data menggunakan model analisis data Miles dan Huberman yaitu Pengumpulan data, Reduksi data, Penyajian data dan penarikan kesimpulan. Hasil penelitian menunjukkan bahwa tradisi mandi bakumbo menjadi salah satu fokus kebudayaan yang keberadaannya diakui secara adat istiadat dan sebagai warisan budaya oleh masyarakat Kota Pekanbaru, selain itu tradisi ini memiliki makna dan nilai yang penting bagi masyarakat Kota Pekanbaru.
\end{abstract}

Kata Kunci: esensi, mandi bakumbo, tradisi Melayu.

\begin{abstract}
This study aims to describe the procession and essence of the Mandi Bakumbo event in a Malay traditional wedding in Pekanbaru, Riau Province. The approach used to parse the results of research is the approach of art, culture and essence. The research method used is descriptive qualitative. Data collection is done by Observation (documentation) and Interview (Interview). Data analysis techniques using the Miles and Huberman data analysis models, namely data collection, data reduction, data presentation and conclusion drawing. The results of the study showed that the tradition of mandi bakumbo became one of the focuses of culture whose existence was recognized in customs and as a cultural heritage by the people of Pekanbaru City, in addition this tradition had significance and value for the people of Pekanbaru City.
\end{abstract}

Keywords: essence, mandi bakumbo, Malay tradition.

\section{PENDAHULUAN}

Provinsi Riau menyimpan kekayaan budaya dan adat istiadat dengan keberagamannya seperti salah-satunya kegiatan mandi bakumbo, merupakan sebuah kegiatan setelah (pasca) dilangsungkannya pesta perkawinan yang diwariskan secara turun-temurun dari setiap generasi ke generasi sebagai warisan budaya. Dalam konteks adat dan budaya, hal ini merupakan sebagian kebudayaan suatu kolektif yang tersebar dan diwariskan secara tradisional dalam versi yang berbeda, baik dalam bentuk lisan maupun contoh yang disertai dengan gerak isyarat atau alat pengingat mnemonic device. Hukum adalah fenomena mental (mental aspect)". Dengan demikian dapat dipahami macam-ragam bentuk adat dan budaya ini mewujud di setiap daerahnya lintas kota dan kabupaten hingga ke setiap desa-desa dalam wilayah administratif dalam provinsi Riau sebagai bentuk (bukti) peninggal leluhur bangsa Melayu.

Berdasarkan fakta-fakta yang ada fakta dan data lapangan maupun hasil wawacara pada beberapa sumber terdapat bukti-bukti bahwa prosesi pernikahan tidak lagi sebagaimana yang diwariskan oleh pada leluhur bangsa Melayu itu sendiri. Sebagaimana dilansir Riaupos.com 8 agustus 2019 dalam tajuk berita "Rencanakan Pesta Pernikahan Tanpa Stres", mengabarkan ada tujuh tips anti stres bagi calon pengantin yang bisa ditiru, salah satunya seperti menyiapkan wedding organizer atau wedding planner dan lain sebagainya, kondisi ini terapliksi karena masyarakat sudah belajar dari pengalaman terdahulu, dimana belajar adalah "kemampuan yang dimiliki oleh seseorang setelah menerima pengalaman belajar yang meliputi seluruh mental" (Mesra, 2016: 308). 


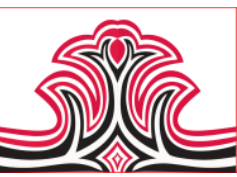

Kegiatan mandi bakumbo, yang merupakan sebuah kegiatan yang dilakukan setelah (pasca) dilangsungkannya pesta perkawinan "setelah dilaksankannya prosesi ijab kabul (pernikahan) kedua mempelai".

Berdasarkan fakta yang dapatkan dilapangan, saat ini sudah sangat sedikit bahkan dari kalangan orang tuatua Melayu Riau yang mampu menjelaskan apa sesungguhnya esensi dari kegiatan mandi bakumbo itu sendiri, kalaupun hal itu ada, tidak lain hanya dalam bentuk tafsiran-tafsiran dari apa yang ia pernah lihat saja melalui orang-orang terdahulu mengenai prosesi mandi taman itu sendiri.

\section{KAJIAN TEORI}

\section{Teori Kebudayaan}

Teori kebudayaan adalah usaha untuk mengonseptualisasikan suatu makna dalam kontkes adat-budaya dalam suatu sosial masyarakat agar dapat memahami pertalian antara data dan fakta satu manusia pada kelompok manusia yang mewujudkan dalam bentuk adat dan kebudayaan dalam sosial masyarakat. Dengan kata lain, teori kebudayaan adalah usaha konseptual untuk memahami bagaimana manusia menggunakan kebudayaan untuk melangsungkan kehidupannya dalam kelompoknya dan memelihara keseimbangannya dengan dunia supranatural. Terkait teori transformasi budaya sebagai midlle theory pada penelitian Tradisi Mandi Bakumbo pada Acara Pernikahan Adat Melayu di Pekanbaru Provinsi Riau ini, menurut Ismawati (2012: 100), transformasi budaya secara teoritis diartikan sebagai suatu proses dialog yang terus menerus antara kebudayaan lokal dengan kebudayaan luar "donor" sampai pada tahap tertentu membentuk proses sintesa dengan berbagai wujud yang akan melahirkan format akhir budaya yang mantap. Senada dengan Ismawati ditambahkan oleh Burhan Bungin, (2011:111) bahwa, sebahagian kebudayaan suatu kolektif yang tersebar dan diwariskan secara turun-temurun, diantara kolektif macam apa saja, secara tradisional dalam versi yang berbeda, baik dalam bentuk lisan maupun contoh yang disertai dengan gerak isyarat atau alat pengingat mnemonic device.

\section{Perkawinan dalam Adat Budaya Melayu}

Secara dharuri (mendasar) pernikahan adat-budaya Melayu Riau selain bertujuan menjaga nilai-nilai budaya warisan leluhur agar tak lekang di panas-lapuk di hujan (digerusi zaman), merupakan suatu upacara sakral yang sarat akan nilai yang bersifat agamis yang suci (nilai religiusitas). Dengan kata lain, pernikahan pada adat Melayu Riau bukan hanya sebatas
Gorga Jurnal Seni Rupa

Volume 09 Nomor 01 Januari-Juni 2020

p-ISSN: 2301-5942 | e-ISSN: 2580-2380

pemenuhan kebutuhan biologis manusia (syahwat) semata maupun menjaga spesies manusia agar tetap eksis, melainkan juga suatu perintah langsung dari Allah SWT. Dalam pengertian, adat-budaya yang telah berlaku dan diterpakan sejak berabad-abad yang lampau, seiring dengan adanya orang Melayu di dunia ini. Nilai-nilai dasar inilah yang selama berabad-abad silam telah mampu menciptakan kehidupan yang sejahterah lahir-bathin dengan macam-ragamnya suku bangsa di bumi Melayu. Dengan kata lain melahirkan sebuah tamadun di tanah Melayu. Terdapat 8 klasifikasi nilai-nilai dasar yang terkandung di dalam adat-budaya Melayu, menurut Tenas Effendy, (2004: 69-78) antara lain adalah sebagai berikut ini.

Tabel 1. Nilai-nilai dasar adat budaya Melayu

\begin{tabular}{|ll|ll|}
\hline \multicolumn{2}{|c|}{$\begin{array}{c}\text { NILAI-NILAI DASAR YANG TERKANDUNG } \\
\text { DALAM ADAT-BUDAYA MELAYU }\end{array}$} \\
\hline • & Keterbukaan & $\bullet$ & Kebersamaan \\
- & Religius (islam) & • & Cita-Cita Bersama \\
- & Nasab Keturunan & • & Kekuasaan dan Martabat \\
- & Moral dan Etika & $\bullet$ & Musyawarah \\
\hline
\end{tabular}

\section{METODE PENELITIAN}

Permasalahan yang diteliti merupakan masalah yang bersifat dinamis dan tidak stagnant. Oleh karena itu pada penelitian tradisi mandi bakumbo pada acara pernikahan adat melayu di Pekanbaru Provinsi Riau ini menggunakan metode penelitian deskriptif kualitatif untuk menentukan cara mencari, mengumpulkan, mengolah dan menganalisis temuan data tradisi mandi bakumbo pada acara pernikahan adat melayu di Pekanbaru Provinsi Riau. Penelitian tradisi tradisi mandi bakumbo pada acara pernikahan adat melayu di Pekanbaru Provinsi Riau berusaha mendeskripsikan suatu fenomena/peristiwa secara sistematis sesuai dengan apa adanya. Pendekatan Kualitatif menguraikan suatu fenomena tentang lingkungan maupun kehidupan sosial dalam masyarakat (Bungin, 2010:40). Lokasi penelitian ini bertempat di Tanjung RHU, Kecamatan Lima Puluh Kota Pekanbaru Provinsi Riau.

Teknik pengumpulan data pada penelitian ini adalah kajian pustaka, observasi, wawancara dan dokumentasi. Teknik keabsahan data menggunakan teknik-teknik perpanjang keikutsertaan, ketekunan pengamatan dan triangulasi. Teknik analisis data yang mempunyai komponen yang berkaitan yaitu sebagai berikut: pengumpulan data, reduksi data, penyajian data dan penarikan kesimpulan.

\section{HASIL DAN PEMBAHASAN}

\section{Hasil}

Mandi bakumbo ini juga disebut sebagai mandi berhias atau mandi di halaman, sebab kegiatan mandi ini 
dilakukan di sebuah tempat yang disebut dengan panca persada yang dihias seindah mungkin. Tradisi mandi ini dilaksanakan di halaman rumah dan juga disaksikan oleh khalayak ramai.

Sebelum ritual mandi bakumbo dimulai, pengantin terlebih dahulu ditepuk tepung tawar oleh kedua belah pihak keluarga. Beda dengan ritual tepuk tepung tawar saat bersanding, pada tepuk tepung tawar mandi bakumbo pengantin ini, disediakan telur ayam kampung dahulu. Gunanya saat ditepung tawar dilakukan, ayam kampung diletakkan diatas batu gerinda yang dialasi cincin mas kawin kemudian di putar tiga kali didepan muka pengantin lalu telur ditempelkan didekat gigi. Ritual tepung tawar ini dilakukan oleh orang tua pengantin atau orang yang dituakan didalam kedua pihak keluarga pengantin seperti Pak Cik (paman) atau Mak Cik (bibi). Usai tepung tawar baru mandi taman dimulai.

\section{Pembahasan}

\section{1).Peralatan Tradisi Mandi Bakumbo dalam Pernikahan Adat Melayu di Kecamatan Lima Puluh Kota Pekanbaru Provinsi Riau.}

Perlengkapan alat yang dipersiapkan dalam mandi bakumbo ini adalah pertama, dua buah talam besar yang terbuat dari tembaga, yang biasa disebut talam tidak berkelium tepi. Peralatan yang kedua yaitu sebuah pasu kecil atau tempayan kecil yang berisi air sumur atau air sungai. Peralatan alat yang ketiga yaitu sebuah pasu kecil atau tempayan kecil yang berisikan air, pada lehernya dililit dengan daun pandan yang dipotong persegi. Air dalam tempayan ini dinamakan air tolak bala. Keempat yaitu sebuah cermin muka atau kaca muka. Selanjutnya perlengkapan alat yang kelima yaitu kendi yang telah diisi oleh air bersih dan perlengkapan alat yang kedelapan adalah batu asah.

\section{2).Bahan-bahan Tradisi Mandi Bakumbo dalam Pernikahan Adat Melayu di Kecamatan Lima Puluh Kota Pekanbaru Provinsi Riau}

Perlengkapan bahan-bahan yang dipersiapkan dalam mandi bakumbo ini adalah pertama adalah daun kelapa berwarnakan hijau muda, kemudian yang kedua adalah daun pandan yang hijau tua. Kemudian yang ketiga adalah mayang kelapa yang berwarna kuning keemasan, selanjutnya yang keempat yaitu mayang pinang yang berwarna hijau muda. Perlengkapan bahan-bahan yang kelima yaitu lilin kemudian yang keenam yaitu sebutir kelapa yang sudah dikupas kulit luarnya dan dibentuk seperti puncak gunung. Ditengahtengah puncak gunung itu dililit pula tiga lembar benang berwarna putih, hitam dan merah tua, ketujuh, selembar daun kelapa muda disimpul hidup. Kemudian
Gorga Jurnal Seni Rupa

Volume 09 Nomor 01 Januari-Juni 2020

p-ISSN: 2301-5942 | e-ISSN: 2580-2380

perlengkapan bahan-bahan ketujuh adalah bunga tujuh rupa, yang kedelapan yaitu bunga rampai. Yang kesembilan adalah padi yang berwarna kuning keemasan dan yang kesepuluh yang adalah beras yang berwarna putih. Kemudian yang kesebelas adalah daun tepak sirih yang berwarna hijau tua dan yang kedua belas adalah telor ayam kampung yang berwarna putih bersih. Selanjutnya yang ketiga belas adalah kain selendang putih, kemudian yang keempat belas uang logam dan yang kelima belas yaitu 7 pes cincin emas/cincin perak.

\section{3).Proses Tradisi Mandi Taman dalam Pernikahan Adat Melayu di Kecamatan Lima Puluh Kota Pekanbaru Provinsi Riau.}

Pada ritual mandi bakumbo ini terdapat tahapantahapan atau perosesi yang menjadi bagian utuh terhadap kegiatan ritual mandi bakumbo. Tahapantahapan ini tidaklah sama di setiap daerahnya, hal ini disebabkan oleh banyak faktor namun secara garis besar memiliki tahapan-tahapan yang hampir sama namun hanya berbeda pada penamaannya.

Prosesi Pertama, Pada prosesi ini kedua pengantin keluar dari rumah pengantin perempuan menuju pelaminan panca persada yang ditemani oleh masingmasing perwakilan keluarga, pengantin wanita menggunakan songket sebagai penutup kepala sampai badan. Kedua pengantin berjalan sambil diiringi oleh nyanyian shalawat nabi Muhammad SAW.

Prosesi Kedua, Pada prosesi ini pengantin menggunakan pakaian yang seragam kemudian keduanya didudukan seperti akad nikah, pengantin perempuan menggunakan kerudung dan laki laki memakai baju kurung. Di Pelaminan panca persada telah disiapkan peraalatan tepung tawar, sesaat setelahnya kemudian dilanjutkan dengan prosesi meghasah.

Prosesi Ketiga, Pada prosesi ketiga keluarga dan kerabat terdekat kedua pengantin keluar dari rumah menuju ke pelaminan panca persada sambal membawa peralatan mandi bakumbo. Rombongan keluarga dan kerabat dari kedua pengantin ini berjalan mengelilingi kedua pengantin yang duduk di pelaminan panca persada sambil iringi oleh nyanyian cik cik kendung.

Prosesi Keempat, Prosesi keempat adalah proses memandikan pengantin. Sebelumnya kain putih dasar telah dibentangkan diatas kedua kepala pengantin bertujuan agar air yang disiramkan tidak langsung mengenai pakaian dari kedua pengantin. 


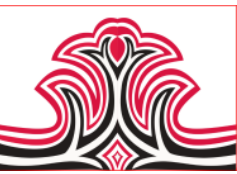

Prosesi Kelima, Prosesi kelima adalah ritual belage. Belage adalah ketika kedua perwakilan dari masingmasing pengantin saling memukulkan dan membenturkan bahan-bahan mandi bakumbo ke bagian atas kain selendang putih.

Prosesi Keenam, Prosesi keenam adalah mandi bunga 7 rupa. Sebelumnya kain putih dasar telah dibentangkan diatas kedua kepala pengantin bertujuan agar air bunga 7 rupa yang disiramkan tidak langsung mengenai pakaian dari kedua pengantin.

Prosesi Ketujuh, Prosesi ketujuh adalah sembur lepas. sembur lepas adalah istilah yang digunakan saat kedua pengantin mengumpulkan air ke dalam mulut mereka melalui air yang ada didalam ceret/kendi dan menyemburkanya.

Prosesi Kedelapan, Prosesi kedelapan adalah meniti talam. Pada tahapan ini kedua pengantin melangkahi talam secara bersama-sama. Setelah selesai mandi pengantin dengan pakaian yang masih basah kemudian mak andam menuntun kedua pengantin untuk berjalan berasama diatas tampi yang sudah disusun sejajar sebanyak 7 buah talam.

Prosesi Kesembilan, Prosesi kesembilan adalah mandi bakumbo. Bakumbo merupakan tahapan penutup dari rentetan panjang ritual mandi taman, pada tahapan ini kedua pengantin dan mak andam melemparkan uang logam ke halaman rumah yang telah berkumpul keluarga, kerabat dekat dan para tetangga yang hadir menyaksikan ritual mandi taman.

\section{4).Esensialitas dalam Tradisi Mandi Bakumbo dalam Pernikahan Adat Melayu di Kecamatan Lima Puluh Kota Pekanbaru Provinsi Riau.}

Setiap tradisi tentu memiliki nilai-nilai yang sakral bagi pelakunya. Di dalam tradisi mandi bakumbo terdapat nilai kemanusiaan, nilai kebersamaan, nilai estetika, nilai kesopanan dan nilai harapan. Nilai-nilai itu tersirat dari keikutsertaan kedua pihak keluarga pengantin untuk terlibat dalam awal prosesi mandi bakumbo sampai akhir prosesi.

\section{(1).Nilai-Nilai Kemanusiaan}

Nilai-nilai kemanusiaan (nilai etika atau moral) merupakan sesuatu yang menyangkut kelakuan dan perbuatan manusia yang sesuai dengan norma dan menghormati martabat manusia. Hal ini menunjukkan bahwa pada prosesi pertama pada ritual tradisi mandi bakumbo pada acara pernikahan adat Melayu di Pekanbaru Provinsi Riau ini merupakan perwujudan dari implementasi Pancasila sila ke-2 yaitu
Gorga Jurnal Seni Rupa

Volume 09 Nomor 01 Januari-Juni 2020

p-ISSN: 2301-5942 | e-ISSN: 2580-2380

kemanusiaan yang adil dan beradap yang memiliki makna bahwa setiap warga negara harus mengakui kelebihan dan kekurangan warga negara yang lainnya serta memperlakukannya sesuai dengan harkat dan martabatnya sebagai mahluk Tuhan Yang Maha Esa, yang sama derajatnya, yang sama haknya dan kewajiban-kewajiban azasinya, tanpa membedabedakan suku, keturunan, agama, dan keparcayaan, jenis kelamin, kedudukan sosial, warna kulit dan sebagainya.

\section{(2).Nilai-Nilai Kesopanan}

Nilai kesopanan pada ritual tradisi mandi taman pada acara pernikahan adat melayu di Kota Pekanbaru Provinsi Riau terdapat pada prosesi Prosesi meghasah adalah ketika orang tua atau keluarga yang yang dituakan seperti pak cik (paman) atau mak cik (bibi) membenturkan secara lembut telur ayam kampung ke gigi pengantin lelaki terlebih dahulu. Telur yang dibenturkan tidaklah sampai pecah melainkan hanya sekedar menempel dan berbunyi ketika dibenturkan ke gigi penganti laki-laki. Selanjutnya mak andam membenturkan telur ke pengantin wanita, telur ayam kampung yang dibenturkan tidaklah sampai pecah melainkan hanya sekedar menempel dan berbunyi ketika dibenturkan ke gigi penganti wanita. Disini peran mak andam hanya sebagai seorang peraga yaitu mengajarkan caranya kepada orang tua atau pak cik dan mak cik pengantin.

Hal inilah yang menjadi nilai kesopanan pada tradisi mandi taman pada acara pernikahan adat melayu di Kota Pekanbaru Provinsi Riau, yaitu ketika pengantin bisa menjaga tutur kata menjadi yang lebih baik ketika berinteraksi sosial di dalam ruang lingkup yang kental dengan standar norma kesopanan dan sanksi norma kesopanan.

\section{(3).Nilai-Nilai Kebersamaan}

Manusia sebagai makhluk sosial tentunya memerlukan orang lain. Semakin banyak dan semakin sering interaksi seseorang dengan orang lain itu juga memupuk nilai-nilai tersendiri. Nilai kebersamaan pada tradisi mandi taman pada acara pernikahan adat melayu di Kota Pekanbaru Provinsi Riau terdapat pada prosesi ketiga, kelima, kedelapan dan kesembilan memiliki makna yaitu ketika suatu kegiatan yang dilakukan secara bersama-sama dan bersifat suka rela maka kegiatan yang dikerjakan dapat berjalan dengan lancar, mudah dan ringan. Karena dengan adanya kesadaran akan untuk menciptakan dan menjaga kebersamaan maka tali silaturahmi akan semakin kuat dan hubungan kekerabatan kedua keluarga akan semakin mambaik, hal ini tentu saja akan mempengaruhi kerharmonisan 


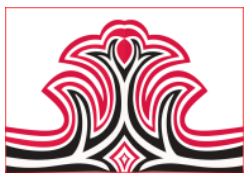

rumah tangga pengantin di masa yang akan datang. Hal inilah yang menjadi nilai kebersaaman pada tradisi mandi taman pada acara pernikahan adat melayu di Kota Pekanbaru Provinsi Riau, yaitu ketika kedua keluarga saling terhubung secara moral bersama-sama dalam suatu kondisi, dalam kegiatan yang sama, menanggung beban yang sama, maka dengan kebersamaan beban yang berat dapat dirasa ringan.

\section{(4).Nilai-Nilai Estetik}

Estetika adalah suatu ilmu yang mempelajari segala sesuatu yang berkaitan dengan keindahan. Nilai estetik sendiri mempunyai arti suatu objek yang memiliki pengaruh terhadap keindahan. Kebersihan merupakan salah satu aspek pendukung nilai estetika. Kebersihan tubuh dan lingkungan merupakan aspek-aspek dalam nilai estetika. Kebersihan diri tidak hanya penting bagi kita, namun jug bagi orang di sekitar kita.

Nilai estetik pada tradisi mandi taman pada acara pernikahan adat melayu di Kota Pekanbaru Provinsi Riau terdapat pada prosesi keempat dan keenam yang bermakna bahwa kedua pengantin senantiasa menjaga kebersihan diri secara lahir dan bathin agar terjaga kenyamanan dan kerukunan berkeluarga serta bagi pengantin wanita untuk selalu menjaga penampilannya dihadapan suami didalam keadaan apapun, guna menjaga keharmonisan dan kehangatan didalam rumah tangga. Hal inilah yang menjadi nilai estetik pada tradisi mandi taman pada acara pernikahan adat melayu di Kota Pekanbaru Provinsi Riau, yaitu ketika kedua pengantin saling menjaga kebersihan diri secara lahiriah dan bathiniah guna terciptanya kerharmonisan, kehangatan dan kerukunan pengantin dalam memulai kehidupan baru sebagai pasangan suami istri.

\section{(5).Nilai Harapan}

Harapan atau asa adalah bentuk dasar dari kepercayaan akan sesuatu yang diinginkan akan didapatkan atau suatu kejadian akan bebuah kebaikan di waktu yang akan datang. Nilai harapan pada tradisi mandi taman pada acara pernikahan adat melayu di Kota Pekanbaru Provinsi Riau terdapat pada prosesi ketujuh yaitu ritual sembur lepas. Hal inilah yang menjadi nilai harapan pada tradisi mandi taman pada acara pernikahan adat melayu di Kota Pekanbaru Provinsi Riau, yaitu ketika kedua pengantin saling berlomba untuk menjadi yang terkuat semburannya agar bisa memiliki pengaruh yang kuat didalam rumah tangga yang akan mereka jalani di masa yang akan datang.

\section{KESIMPULA DAN SARAN 1.Kesimpulan}

Gorga Jurnal Seni Rupa

Volume 09 Nomor 01 Januari-Juni 2020

p-ISSN: 2301-5942 | e-ISSN: 2580-2380

Berdasarkan pembahasan diatas, maka dapat ditarik kesimpulan bahwasanya tradisi mandi taman merupakan salah satu tradisi yang terdapat di Kota Pekanbaru yang masih berlangsung hingga saat ini. Tradisi mandi taman juga menjadi salah satu fokus kebudayaan yang keberadaannya diakui secara adat istiadat dan sebagai warisan budaya oleh masyarakat Kota Pekanbaru. Selain itu tradisi ini memiliki makna dan nilai yang penting bagi masyarakat Kota Pekanbaru.

\section{1). Prosesi Tradisi Mandi Taman Pada Acara Pernikahan Adat Melayu di Kota Pekanbaru Provinsi Riau}

Tradisi mandi ini dilaksanakan di halaman rumah dan juga disaksikan oleh khalayak ramai. Ritual mandi taman bagi pengantin laki-laki dan perempuan melayu dilakukan setelah acara bersanding berlangsung. Tujuanya adalah agar pengantin terhindar dari perbuatan jahat, tercipta saling pengertian dan dapat bekerja sama dan mendapat cahaya mata (anak) yang shaleh dan berbudi pengerti baik serta terhindar dari perbuatan jahat. Pada ritual mandi taman ini terdapat tahapan-tahapan atau perosesi yang menjadi bagian utuh terhadap kegiatan ritual mandi taman. Tahapantahapan ini tidaklah sama di setiap daerahnya, hal ini disebabkan oleh banyak faktor namun secara garis besar memiliki tahapan-tahapan yang hampir sama namun hanya berbeda pada penamaannya.

\section{2). Nilai-nilai Tradisi Mandi Taman Pada Acara Pernikahan Adat Melayu di Kota Pekanbaru Provinsi Riau}

Tradisi mandi taman secara garis besar berkaitan dengan sistem nilai yang berlaku dan masih tetap dipertahankan oleh suku Melayu di Kota Pekanbaru, hal ini merupakan ketelitian suku Melayu di Kota Pekanbaru dalam melestarikan budaya khas mereka, hal ini tentunya melalui tinjauan yang sangat seksama oleh masyarakat tersebut, dimana tinjauan adalah "proses pemeriksaan dalam penyelidikan terhadap peristiwa untuk menentukan masalah atau mengetahui keadaan sebenarnya" (Sitepu, 2020: 33). Selain itu juga terdapat nilai-nilai yang terkandung dalam mandi taman, terlihat pada setiap prosesi yang ada pada mandi taman. Nilai-nilai yang terdapat pada mandi taman merupakan makna kiasan yang disampaikan melalui setiap prosesi mandi taman. Nilai-nilai yang terkandung didalam mandi taman sangat banyak jika ditelusuri secara lebih mendalam, namun dalam hal ini peneliti berhasil menemukan nilai kemanusiaan, nilai kebersamaan, nilai estetika, nilai kesopanan dan nilai harapan. 


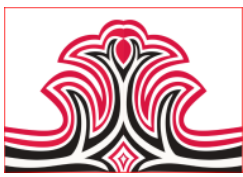

2. Saran

Berdasarkan hasil dari berbagai temuan penelitian yang telah dikemukan, maka dapat diajukan beberapa saran sebagai pihak-pihak berikut ini.

1. Guru Seni Budaya, supaya memasukkan tradisi mandi taman menjadi tambahan dalam bahan ajar seni budaya di sekolah maupun melalui kegiatan ekstrakurikuler.

2. Pemerintah, hendaknya menjadikan penelitian ini dan yang sejenisnya sebagai masukan terhadap program dan kebijaksanaan pemerintah Kota Pekanbaru terhadap usaha dan pembinaan tradisitradisi melayu yang masih eksis dalam ruang lingkup masyarakat Kota Pekanbaru.

3. Masyarakat, agar terus memberikan dukungan untuk memelihara nilai-nilai budaya, mengingat tradisi mandi taman terdapat nilai-nilai yang bermanfaat bagi kehidupan bermasyarakat.

4. Peneliti, agar mencari dan menguraikan lebih luas tentang tradisi mandi taman di masa yang akan datang agar tradisi mandi taman tetap eksis dan menjadi karaketristik suku Melayu di Kota Pekanbaru.

\section{DAFTAR RUJUKAN}

Burhan, Bungin. (2011). Metodologi Penelitian Kualitatif. Rajawali press. Jakarta.

Effendy Tenas. (2004). Pemakaian Ungkapan Dalam Upacara Perkawinan Orang Melayu. Balai kajian. Yogyakarta.

Ismawati Esti. (2012). Ilmu Sosial Budaya Dasar Ombak. Yogyakarta.

Mesra, M., Azis, A. C. K., \& Astuti, W. W. (2016). Kontribusi Motivasi Belajar Dan Lingkungan Tempat Tinggal Terhadap Hasil Belajar Mahasiswa Jurusan Seni Rupa Universitas Negeri Medan. Jurnal Bahas Unimed, 27(3), 302-319.

Riaupos.com. "Rencanakan Pesta Pernikahan Tanpa Stres”. Diunduh pada 8 agustus 2019. [Online]. di www. Riaupos.com.

Sitepu, C., Azmi, A., Ibrahim, A., \& Azis, A. C. K. (2020). Tinjauan Gambar Ekspresi Objek Manusia Berdasarkan Teori Lowenfeld Menggunakan Krayon oleh Anak TK B Methodist Berastagi. Gorga: Jurnal Seni Rupa, 9(1), 32-38. 